\title{
Application of a Schizosaccharomyces pombe Edc1-fused Dcp1-Dcp2 decapping enzyme for transcription start site mapping
}

\author{
DAVID R. PAQUETTE, ${ }^{1}$ JEFFREY S. MUGRIDGE, ${ }^{2}$ DAVID E. WEINBERG, ${ }^{3,4}$ and JOHN D. GROSS ${ }^{1,2}$ \\ ${ }^{1}$ Integrative Program in Quantitative Biology, Graduate Group in Biophysics, University of California, San Francisco, California 94158, USA \\ ${ }^{2}$ Department of Pharmaceutical Chemistry, University of California, San Francisco, California 94158, USA \\ ${ }^{3}$ Department of Cellular and Molecular Pharmacology, University of California, San Francisco, California 94158, USA \\ ${ }^{4}$ Sandler Faculty Fellows Program, University of California, San Francisco, California 94158, USA
}

\begin{abstract}
Changes in the $5^{\prime}$ leader of an mRNA can have profound effects on its translational efficiency with little effect on abundance. Sequencing-based methods to accurately map the $5^{\prime}$ leader by identifying the first transcribed nucleotide rely on enzymatic removal of the $5^{\prime}$ eukaryotic cap structure by tobacco acid pyrophosphatase (TAP). However, commercial TAP production has been problematic and has now been discontinued. $\mathrm{RppH}$, a bacterial enzyme that can also cleave the $5^{\prime}$ cap, and Cap-Clip, a plant-derived enzyme, have been marketed as TAP replacements. We have engineered a Schizosaccharomyces pombe Edc1fused Dcp1-Dcp2 decapping enzyme that functions as a superior TAP replacement. It can be purified from $E$. coli overexpression in high yields using standard biochemical methods. This constitutively active enzyme is four orders of magnitude more catalytically efficient than $\mathrm{RppH}$ at $5^{\prime}$ cap removal, compares favorably to Cap-Clip, and the $5^{\prime}$ monophosphorylated RNA product is suitable for standard RNA cloning methods. This engineered enzyme is a better replacement for TAP treatment than the current marketed use of RppH and can be produced cost-effectively in a general laboratory setting, unlike Cap-Clip.
\end{abstract}

Keywords: mRNA caps; mapping mRNA 5' ends; decapping enzymes; RppH; Dcp2; transcript leaders

\section{INTRODUCTION}

The $5^{\prime}$ leaders, often referred to as $5^{\prime}$ UTRs, are important for gene regulation in both normal and disease states (Calvo et al. 2009; Dieudonné et al. 2015), making it crucial to accurately identify them. Changes in the $5^{\prime}$ leader sequence of transcripts can have large effects on translational efficiencies, despite no change in transcript levels (Calvo et al. 2009; Rojas-Duran and Gilbert 2012). Several methods have been developed to map $5^{\prime}$ transcription start sites (TSSs), both of individual mRNAs (Volloch et al. 1994; Carninci and Hayashizaki 1999) and genome-wide (Carninci et al. 2000; Machida and Lin 2014). The most widely used TSS mapping technique, 5' RACE, depends on the enzymatic removal of the $5^{\prime}$ cap (Schaefer 1995). Tobacco acid pyrophosphatase (TAP) has been used for decades as a reagent for cap removal (Lockard et al. 1981), despite it not being the natural decapping enzyme and the difficulty in purifying it directly from tobacco plants. In fact, the TAP protein sequence is still unknown. This has led to the discontinuation of TAP pro-

Corresponding author: jdgross@cgl.ucsf.edu

Article is online at http://www.rnajournal.org/cgi/doi/10.1261/rna. 062737.117. duction with no suitable replacement on the market. New England Biolabs (NEB) has marketed $\mathrm{RppH}$ as a TAP replacement; however, it too is not a natural $\mathrm{m}^{7} \mathrm{G}$ decapping enzyme (Deana et al. 2008). Instead it is specific for triphosphorylated bacterial mRNAs. Another plant-derived enzyme, Cap-Clip (CELLSCRIPT), has recently become commercially available as a TAP replacement. The sequence of that enzyme is also unknown and therefore it cannot be recombinantly expressed in a general laboratory setting. A readily available, easy to produce, and efficient enzyme with specificity for the eukaryotic $5^{\prime}$ mRNA cap that leaves a product with a $5^{\prime}$-monophosphate suitable for ligation is lacking.

Here, we describe an engineered $S$. pombe Dcp1-Dcp2 decapping complex fused to its Edcl activator peptide as a fast and efficient TAP replacement for mapping TSSs. This enzyme is recombinantly expressed in E. coli and readily purified using Ni-NTA affinity, followed by size-exclusion

(C) 2018 Paquette et al. This article is distributed exclusively by the RNA Society for the first 12 months after the full-issue publication date (see http://rnajournal.cshlp.org/site/misc/terms.xhtml). After 12 months, it is available under a Creative Commons License (Attribution-NonCommercial 4.0 International), as described at http://creativecommons.org/licenses/by$\mathrm{nc} / 4.0 /$. 
chromatography. Our purified enzyme was compared sideby-side with $\mathrm{RppH}$ and showed four orders of magnitude greater catalytic efficiency in an in vitro decapping assay. Our enzyme also compared favorably with the Cap-Clip reagent. We also demonstrate that the $5^{\prime}$ end of the enzymatically treated total RNA can be cloned onto an RNA adaptor oligo using standard methods and is able to accurately map the first transcribed nucleotide of a known transcript. This easy to produce decapping enzyme is a superior TAP replacement for both gene-specific and genome-wide methods for mapping the $5^{\prime}$ end of RNAs.

\section{RESULTS}

\section{Design and construction of a constitutively active decapping enzyme}

The fungal Dcp1-Dcp2 decapping complex is a stable, obligate heterodimer that can be recombinantly expressed in E. coli with high yields. The activity of Dcp1-Dcp2 can be significantly enhanced by Edcl-like coactivators that contain unstructured, short-linear motifs that bind Dcp1 and activate catalysis by Dcp2 (Borja et al. 2011; Lai et al. 2012; Mugridge et al. 2016; Valkov et al. 2016; Wurm et al. 2016; Schütz et al. 2017). We set out to design a constitutively active decapping complex consisting of the core SpDcp1-Dcp2 heterodimer stably bound to the minimal activation sequence of the Edc1 coactivator. We designed an IPTG-inducible single plasmid coexpression system consisting of GB1-tev-Dcp1 and hexahistadine-TRX-tev-Edc1-GSlinker-Dcp2, where the conserved Dcp1-binding and Dcp2-activating motifs of SpEdc1, residues 155-186, are covalently fused to the $\mathrm{N}$ terminus of Dcp2 by a flexible GS linker (Fig. 1A,B). The covalent linkage of the Edc1 peptide served to simplify the expression and purification of the activated complex. We designed the single-chain Edc1-Dcp2 fusion (hereafter denoted scEdc1Dcp2) with a 10 residue $\left(\mathrm{G}_{4} \mathrm{SG}_{4} \mathrm{~S}\right)$ linker, which copurifies in complex with Dcp1. The Dcp1-scEdc1Dcp2 complex was eluted off Ni-NTA and the solubility tags were fully cleaved after TEV treatment (Fig. 1C). Size-exclusion chromatography revealed that the 10 residue linker allows Edc1 to bind the Dcp1-Dcp2 complex in cis, forming predominantly a Dcp1-scEdc1Dcp2 heterodimer. The shoulder of the peak consists of Edcl binding in trans to another Dcp1-Dcp2 complex, forming a dimer of heterodimers (Fig. 1D). We used sample from the dominant, Dcp1scEdc1Dcp2 peak (Fig. 1D, denoted with an asterisk) for all further experiments.

\section{Dcp1-scEdc1Dcp2 enzyme is more catalytically efficient than RppH and is comparable to Cap-Clip}

$\mathrm{RppH}$ is currently one of the most readily available enzymes for $5^{\prime} \mathrm{m}^{7} \mathrm{G}$ cap removal from eukaryotic RNA for in vitro biochemical applications, since the discontinuation of TAP pro- duction. We set out to benchmark our constitutively active Dcp1-scEdc1Dcp2 enzyme against a current industry standard. We performed a series of decapping assays at varying concentrations of enzyme to determine $k_{\text {cat }}$ and $K_{\mathrm{d}}$ under single-turnover conditions, where enzyme is in excess of substrate (Jones et al. 2008). Under these assay conditions, we determined a $k_{\text {cat }}$ of $8.44 \mathrm{~min}^{-1}$ and a $K_{\mathrm{d}}$ of $0.19 \mu \mathrm{M}$ for Dcp1-scEdc1Dcp 2 at $4^{\circ} \mathrm{C}$. Unfortunately, we were unable to reach the $k_{\text {cat }}$ for $\mathrm{RppH}$, so we instead compared the catalytic efficiencies $\left(k_{\text {cat }} / K_{\mathrm{d}}\right)$ of the enzymes; the catalytic efficiency or specificity constant is a measure of how efficiently an enzyme converts substrates into products. Dcp1scEdc1Dcp2 has a catalytic efficiency over 20,000 times greater than $\mathrm{RppH}$ for $5^{\prime}$ cap cleavage, demonstrating that it is clearly the better reagent for removing the cap structure from eukaryotic RNA (Fig. 2; Supplemental Fig. S2).

Cap-Clip (CELLSCRIPT) is another reagent that is marketed as a replacement for TAP. This enzyme, like TAP, is purified from plant extracts, so the exact sequence and its concentration are not known. Accordingly, we are only able to compare units of activity to concentration of Dcp1scEdc1Dcp2. We performed a series of decapping assays at varying concentrations of Dcp1-scEdc1Dcp2 and units of Cap-Clip at $37^{\circ} \mathrm{C}$ to determine the concentration of our enzyme that is equivalent to units of Cap-Clip. Since Cap-Clip is not a metal-dependent enzyme (in contrast to $\mathrm{RppH}$ and Dcp2), we took time points by quenching the reactions with a denaturing buffer ( $8 \mathrm{M}$ urea solution containing $7 \%$ SDS). We quenched reactions containing decapping enzyme as usual with EDTA. Under these reaction conditions, 0.29 $\mathrm{nM}$ of Dcp1-scEdc1Dcp2 or more exactly, $1.3 \times 10^{-14}$ moles, is equivalent to 1 unit of Cap-clip reagent in a $45 \mu \mathrm{L}$ volume (Table 1; Supplemental Fig. S1). So, a 1 L preparation of Dcp1-scEdc1Dcp2 would yield a conservative estimate of between 15 and 50 million equivalent units of Cap-Clip.

\section{Downstream RNA cloning applications demonstration}

While Dcp1-scEdc1Dcp2 is a capable enzyme for eukaryotic RNA 5' cap removal, we wanted to ensure that the treated RNA was suitable for downstream cloning applications. We decided to use the previously reported splinted-ligation assay (Blewett et al. 2011; Wang et al. 2013) as verification that (i) we could detect the decapping of an mRNA (rps23) from bulk $S$. pombe purified RNA, and (ii) we could use a cloning method that requires a $5^{\prime}$ monophosphate and an intact first-transcribed nucleotide. We treated three $20 \mu \mathrm{g}$ samples of purified S. pombe total RNA (Supplemental Fig. S2) with $1 \mu \mathrm{M}$ Dcp1-scEdc1Dcp2 and quenched the reaction after 15,30 , and $60 \mathrm{~min}$ by addition of phenol-chloroform. The quenched reactions were ethanol precipitated and taken through the splinted-ligation procedure as detailed in Fig. 3A. The final PCR products of the splinted-ligation reaction were visualized by SYBR Gold staining of a 2\% TAE agarose gel (Fig. 3B). All three samples had a similar amount of total 
A

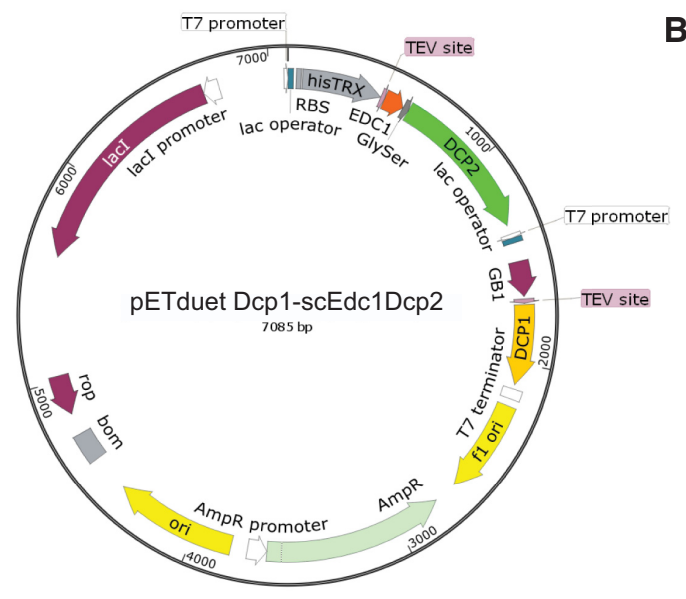

B
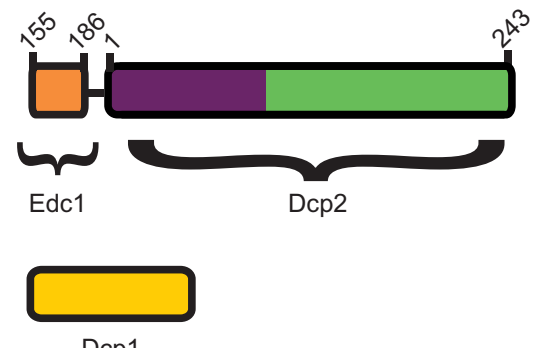

Dcp1
C

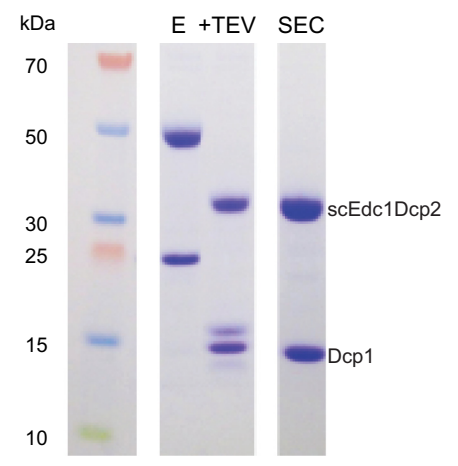

D

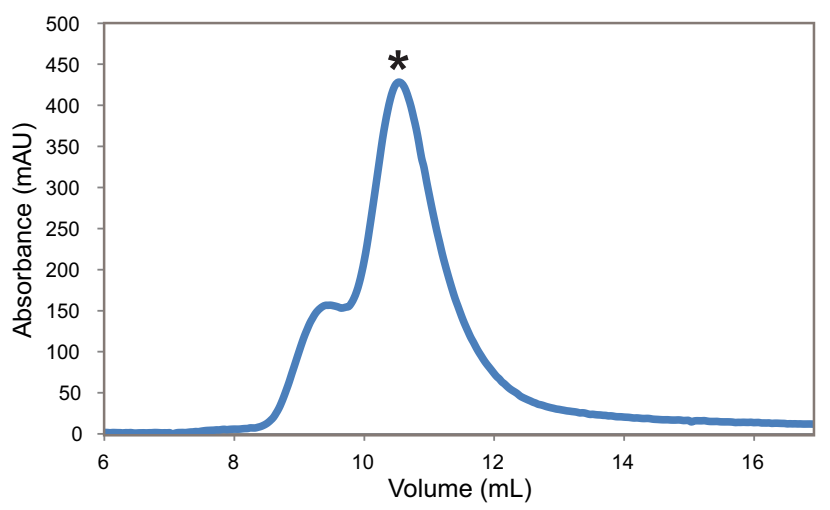

FIGURE 1. (A) E. coli overexpression plasmid constructed from a pETduet with Gb1-tev-Dcp1 in MCS2 and the engineered single-chain his-TRXtev-Edc1(155-186)-(GGGGS) $)_{2}$-Dcp2(1-243) in MCS1. (B) Protein diagram of the engineered Dcp2 decapping enzyme consisting of the minimal activating peptide fragment of Edc1 (orange) fused to the $\mathrm{N}$ terminus of the Dcp2 catalytic core (regulatory domain is purple and catalytic domain is green). Line connecting two proteins is the (GGGGS) ${ }_{2}$ linker. Dcp1 is shown to scale. (C) Coomassie stained SDS-PAGE of the constitutively active decapping enzyme complex after Ni-NTA elution and post-TEV cleavage. The last strip shows the final purified protein complex post size-exclusion chromatography. $(D)$ Analytical size-exclusion chromatogram of the complex on a GE Superdex 75 10/300 GL column. The complex runs as primarily a heterodimer of Dcp1-scEdc1Dcp2, with a smaller amount of a higher-order species, which is likely a dimer of heterodimers.

cDNA product, but the splinted-ligation cDNA product showed a time-dependent increase; consistent with an increase in the amount of decapped and thus ligateable RNA transcript.

Splinted-ligation can generate a ligation product even when the $3^{\prime}$ end of the RNA anchor and the $5^{\prime}$ end of the target mRNA are not perfectly juxtaposed when annealed to the DNA splint (Deana et al. 2008). To demonstrate the reliability of our enzyme to accurately map the first transcribed nucleotide, or TSS, we performed the decapping reaction followed by splinted-ligation on an in vitro transcribed, $\mathrm{m}^{7} \mathrm{G}$ capped nano-luciferase $\mathrm{mRNA}$, where the $5^{\prime}$ terminus is known. We treated $100 \mathrm{ng}$ of RNA with $10 \mathrm{nM}$ of enzyme for $30 \mathrm{~min}$ at $37^{\circ} \mathrm{C}$. The reaction was quenched by extracting with phenol-chloroform, ethanol precipitated, and then taken through the splinted-ligation procedure. The PCR products of the splinted-ligation were visualized in a $2 \% \mathrm{TAE}$ agarose gel using ethidium bromide (Fig. 3C), and were subsequently purified using a QIAquick PCR Purification Kit
(QIAGEN). The product was then sequenced to verify that the RNA anchor was ligated directly to the known TSS. We consistently saw that the first transcribed nucleotide was captured by sequencing following ligation. While we only show one cloning method here, any protocol that requires removal of a $5^{\prime} \mathrm{m}^{7} \mathrm{G}$ capped mRNA to produce a $5^{\prime}$ monophosphate should be well suited to rapid enzymatic cap cleavage with Dcp1-scEdc1Dcp2.

\section{DISCUSSION}

With our increased understanding of the large effects that alternate $5^{\prime}$ transcription leaders can have on protein expression (Curran and Weiss 2016; Young and Wek 2016), it is important to map this sequence space in relation to human disease (Barbosa et al. 2013). Methods to identify transcription start sites rely on the removal of the $5^{\prime}$ eukaryotic cap structure, followed by deep sequencing. Here we have detailed the construction of a constitutively activated $S$. pombe 


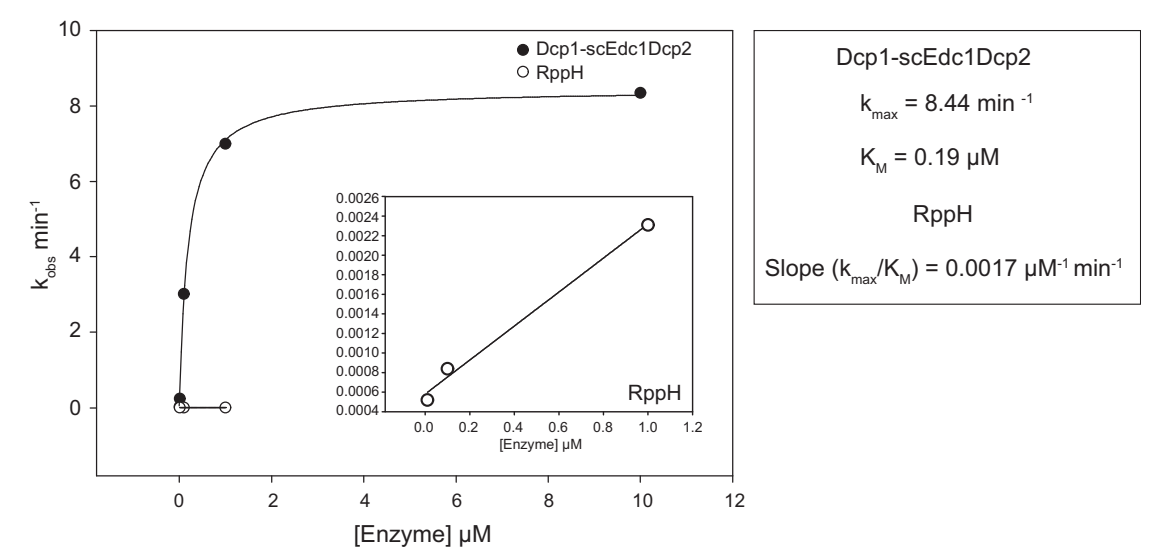

FIGURE 2. Plot of enzyme concentration versus $k_{\text {obs }}$ in a single-turnover decapping kinetics assay on a budding yeast MFA2 mRNA, as monitored by the release of $\left[\alpha^{-32} \mathrm{P}\right] \mathrm{m}^{7} \mathrm{GDP}$ detected by TLC and autoradiography, comparing the activity of the Dcp1-scEdc1Dcp2 enzyme (filled circles) and $\mathrm{RppH}$ (open circles) at $4^{\circ} \mathrm{C}$. $\mathrm{RppH}$ is fit linearly to extract $k_{\text {cat }} / K_{\mathrm{d}}$, and DcplscEdc1Dcp2 enzyme is fit to a rectangular hyperbola to obtain both $k_{\text {cat }}$ and $K_{\mathrm{d}}$ (Jones et al. 2008). cleavage site). The single chain Edc1-Dcp2 fragment was cloned into MCS1 of a Novagen pETduet expression vector containing GB1-tev-SpDcp1(1-127) in MCS2. The Dcp1-scEdc1Dcp2 construct was expressed in E. coli BL21-star DE3 cells (Invitrogen) grown in LB media with an induction time of $18 \mathrm{~h}$ at $20^{\circ} \mathrm{C}$. Cells were harvested at $5000 \mathrm{~g}$, lysed by sonication, and clarified at $16,000 \mathrm{~g}$ in lysis buffer $(50 \mathrm{mM}$ sodium phosphate $\mathrm{pH} 7.5,300 \mathrm{mM}$ sodium chloride, 10 $\mathrm{mM}$ imidazole, $5 \%$ glycerol, $10 \mathrm{mM}$ 2-mercaptoethanol, Roche EDTA-free protease inhibitor cocktail). The protein complex was purified by Ni-NTA affinity chromatography and solubility/affinity tags were cleaved by treatment with TEV protease overnight at room temperature. Dcp1-scEdc1Dcp2 complex was separated from cleaved tags by sizeexclusion chromatography on a GE Superdex 75 16/60 gel filtration column in SEC buffer

decapping complex consisting of Dcp1 and Dcp2 with the conserved coactivator sequence from Edc1 fused to Dcp2 (Dcp1-scEdc1Dcp2). This complex is an excellent replacement for TAP that can be overexpressed in traditional recombinant E. coli expression systems and is readily purified using standard methods. Furthermore, we have demonstrated that Dcp1-scEdc1Dcp2 is at least four orders of magnitude more catalytically efficient than $\mathrm{RppH}$, a bacterial enzyme that has recently functioned as a less efficient substitute for TAP. Additionally, we show that a $1 \mathrm{~L}$ preparation of our engineered enzyme is the equivalent of between 15 and 50 million units of Cap-Clip, an enzyme that is purified from plant extracts. Finally, we have shown that our Dcp1-scEdc1Dcp2 construct can decap an endogenous mRNA from $S$. pombe total RNA, that the resulting product is suitable for RNA cloning methods that make use of a $5^{\prime}$ monophosphate, and that we can accurately map the first transcribed nucleotide using this procedure. Although other decapping enzymes have been described (Grudzien-Nogalska and Kiledjian 2017) and could in principle be used for mapping $5^{\prime}$ ends, the high expression yield (30 mg/L) and catalytic efficiency of Dcp1-scEdc1Dcp2 make it an excellent alternative to what is currently available. Our engineered enzyme is thus a rapid, efficient, and easily prepared reagent that can be used in all biochemical applications requiring removal of the $5^{\prime}$ mRNA cap.

\section{MATERIALS AND METHODS}

\section{Plasmid construction and protein purification}

The single chain his-TRX-tev-SpEdc1(155-186)-(GGGGS) $2_{2}$ SpDcp2(1-243) construct (Edc1-Dcp2 with 10 residue linker) was obtained as an E. coli codon-optimized DNA sequence from Integrated DNA Technologies (his is hexahistidine affinity tag, TRX is thioredoxin solubility tag, tev is Tobacco Etch Virus protease
(50 mM HEPES pH 7, $150 \mathrm{mM} \mathrm{NaCl}, 1 \mathrm{mM}$ DTT). The purified complex was concentrated to $14 \mathrm{mg} / \mathrm{mL}$ and flash frozen in liquid nitrogen. $\mathrm{RppH}$ was purified as previously described (Deana et al. 2008), with some modifications: Standard BL21(DE3) NEB cells were used, and a size-exclusion chromatography step on a GE Superdex 75 16/60 gel filtration column in SEC buffer $(50 \mathrm{mM}$ HEPES pH 7, $150 \mathrm{mM} \mathrm{NaCl}, 1 \mathrm{mM}$ DTT) was added to separate the enzyme from a nucleic acid contaminant.

\section{In vitro decapping assays}

Single-turnover in vitro decapping assays were carried out in decapping buffer $\left(50 \mathrm{mM}\right.$ Tris- $\mathrm{Cl}\left[\mathrm{pH} 7.5\right.$ at $\left.25^{\circ} \mathrm{C}\right], 50 \mathrm{mM}$

TABLE 1. Table comparing the observed rates of Dcp1-scEdc1 and Cap-Clip at $37^{\circ} \mathrm{C}$ under single-turnover conditions

\begin{tabular}{lc}
\hline Dcp1-scEdc1Dcp2 $(\mu \mathrm{M})$ & $K_{\text {obs }}\left(\mathrm{min}^{-1}\right)$ \\
\hline 10 & $10.8 \pm 0.21$ \\
1 & $1.1 \pm 8.7 \times 10^{-1}$ \\
0.1 & $0.045 \pm 4.6 \times 10^{-1}$ \\
\hline Cap-Clip (units) & \\
\hline 10 & $9.9 \pm 0.14$ \\
5 & $4.1 \pm 0.73$ \\
1 & $0.27 \pm 0.080$ \\
\hline
\end{tabular}

The values shown are the average of two replicates and the error is population standard deviation $(\sigma)$. The linear fits derived from each respective set of either concentration versus observed rate (Dcp1-scEdc1Dcp2) or units versus observed rate (Cap-Clip) follow:

$$
\begin{array}{rl}
(\text { Dcp1-scEdc1Dcp2 }): k_{\mathrm{obs}}=1 & .0822\left(\mathrm{~min}^{-1} \mathrm{~nm}^{-1}\right) \\
& \times[\mathrm{Dcp} 1-\mathrm{scEdc1Dcp} 2](\mathrm{nM}) \\
& -0.0430\left(\mathrm{~min}^{-1}\right) \\
(\text { Cap-Clip }): k_{\mathrm{obs}} & \\
=1.0686\left(\mathrm{~min}^{-1} \mathrm{U}^{-1}\right) \times \operatorname{Cap}-\mathrm{Clip}(\mathrm{U})-0.9590\left(\mathrm{~min}^{-1}\right)
\end{array}
$$


A

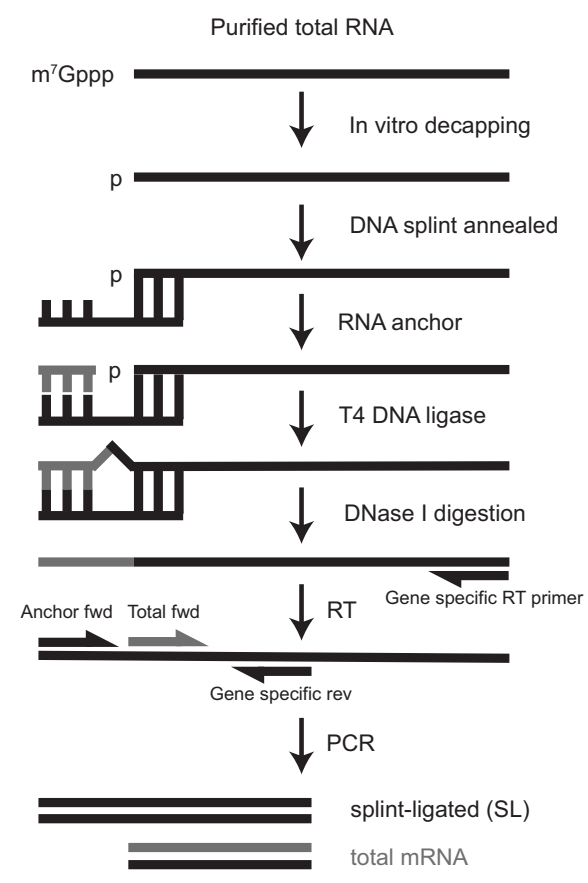

B

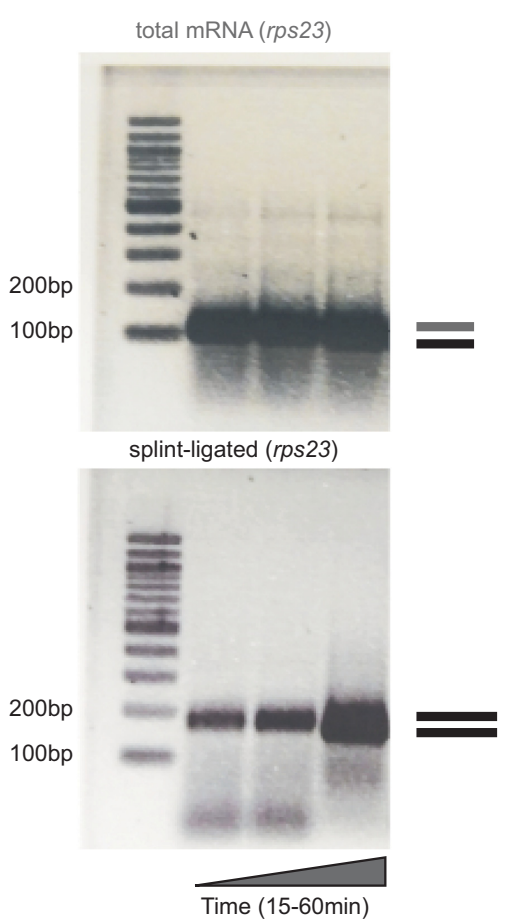

C

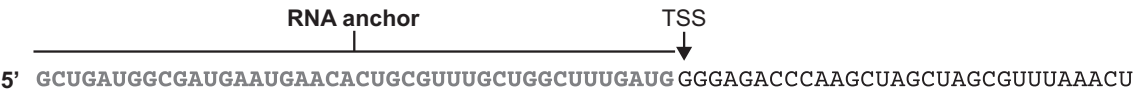

5' GCUGAUGGCGAUGAAUGAACACUGCGUUUGCUGGCUUUGAUG GGGAGACCCAAGCUAGCUAGCGUUUAAACU

Splint 3' CGACTACCGCTACTTACTTGTGACGCAAACGACCGAAACTAC CСCTCTGGGTTCGATCGATCGCAAATTTGA

Expected RT product of splinted-ligation

GCTGATGGCGATGAATGAACACTGCGTTGGTGGCTTTGATGGGGAGACCCAAGCTAGCTAGCGTTAAACT

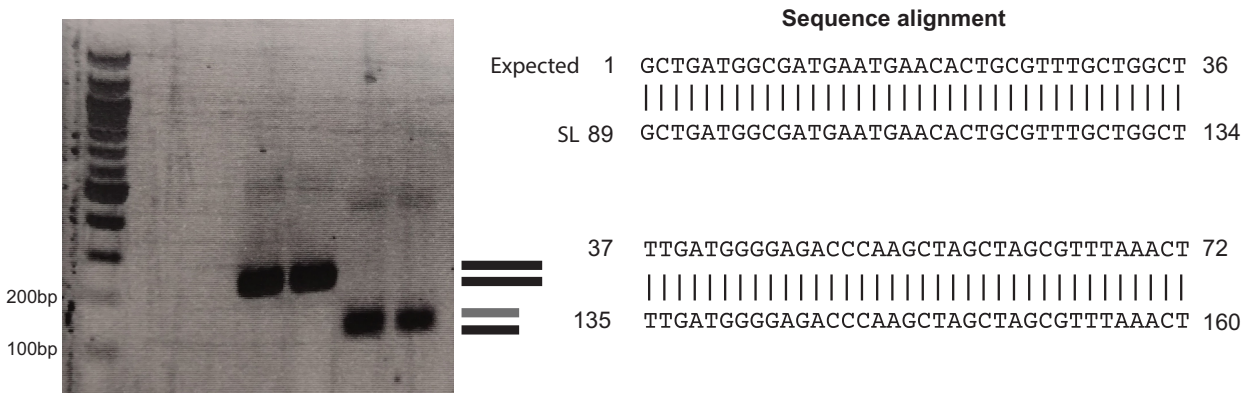

FIGURE 3. (A) Schematic of the splinted-ligation RT-PCR assay used to monitor the decapping of endogenous $r p s 23$ mRNA. Only decapped RNA will produce a PCR product using the anchor forward primer. The RNA anchor oligo will only ligate if there is a free $5^{\prime}$ monophosphate, such as the one produced upon decapping. $(B) 2 \%$ TAE-agarose gels of the splinted-ligation reaction following treatment with $1 \mu \mathrm{M}$ Dcp1-scEdc1Dcp2 enzyme for 15, 30, or $60 \mathrm{~min}$. The top gel is the PCR product representing the total amount of $r p s 23$ transcript, and the bottom gel is of the splinted-ligated product (i.e., decapped $r p s 23$ transcript). There is a time-dependent increase of the splinted-ligated PCR product. $(C)$ Diagram of splinted-ligation of an in vitro transcribed nano-luciferase mRNA annealed to a specific DNA splint and juxtaposed with a specific RNA anchor sequence. The expected RT-PCR product of this ligation is shown below. The 2\% TAE-agarose gel shows the splinted-ligated product (decapped) and total transcript (colored as in $A$ and $B$ ). The alignment to the right is one alignment of the sequencing of a splint-ligated product with the expected nucleotide sequence, showing that the ligation of the RNA anchor occurs directly with the TSS.

$\mathrm{NH}_{4} \mathrm{Cl}, 0.01 \% \mathrm{NP}-40,1 \mathrm{mM}$ DTT, $5 \mathrm{mM} \mathrm{MgCl}_{2}$ ) as previously described (Jones et al. 2008). A ${ }^{32} \mathrm{P}$-labeled 355-nt RNA substrate [containing a 15-nt poly(A) tail] derived from S. cerevisiae MFA2 mRNA was used for all the decapping assays; where the $\mathrm{m}^{7} \mathrm{G}$ cap is radiolabeled on the a phosphate such that, upon decapping, the excised $\mathrm{m}^{7} \mathrm{GDP}$ product could be detected by TLC and autoradiography. Reaction volumes were $45 \mu \mathrm{L}$ total where final Dcp1-
scEdc1Dcp2 or RppH concentration, or units Cap-Clip were varied and the final RNA concentration was $<100 \mathrm{pM}$. Assays were performed at $4^{\circ} \mathrm{C}$ to ensure we could more accurately measure the rate of the chemical step of Dcp1-scEdc1Dcp2, which is too rapid to follow by manual pipetting at room temperature. Time points were quenched by addition of excess EDTA except for Cap-Clip reactions, which were quenched by addition of $6 \mu \mathrm{L}$ reaction to $1 \mu \mathrm{L}$ of 
an $8 \mathrm{M}$ urea solution containing 7\% SDS. Assays comparing CapClip and Dcp1-scEdc1Dcp2 were performed at $37^{\circ} \mathrm{C}$. TLC was used to separate the RNA from the radiolabeled product $\mathrm{m}^{7} \mathrm{GDP}$, and the fraction decapped was quantified with a GE Typhoon scanner and ImageQuant software. Fraction $\mathrm{m}^{7} \mathrm{GDP}$ versus time were plotted and fit to a first-order exponential to obtain $k_{\text {obs }}$; when the kinetics were too slow to obtain reliable exponential fits, $k_{\text {obs }}$ was obtained from a linear fit of the initial rates by division of the slope by the empirically derived endpoint. The catalytic efficiency $\left(k_{\mathrm{cat}} / K_{\mathrm{d}}\right)$ was obtained as detailed in Jones et al. (2008) for the Dcp1-scEdc1Dcp2 enzyme or by taking the slope from a linear fit for $\mathrm{RppH}$.

\section{Splinted-ligation RT-PCR}

Splinted-ligation RT-PCR was carried out as previously described (Wang et al. 2013), but with some modifications from the Coller Laboratory methods online (http://case.edu/med/coller/how.html). Briefly, $20 \mu \mathrm{g}$ of purified yeast total RNA was treated with $1 \mu \mathrm{M}$ of Dcp1-scEdc1Dcp2 in decapping buffer at $37^{\circ} \mathrm{C}$ for 15,30 , or 60 min before the reaction was quenched and the RNA purified by phenol-chloroform extraction. One-tenth of the volume of $3 \mathrm{M} \mathrm{NaOAc}$ ( $\mathrm{pH} 5.5$ ), $1 \mu \mathrm{L}$ Glycoblue, and 2.5-fold of 100\% ice-cold ethanol were added to the RNA solution. The RNA was precipitated at $-20^{\circ} \mathrm{C}$ overnight. RNA was recovered by centrifugation at $18,000 \mathrm{~g}$ for $30 \mathrm{~min}$ at $4^{\circ} \mathrm{C}$ and the pellet was washed with $70 \%$ ethanol followed by brief vortexing. The RNA was pelleted at $18,000 \mathrm{~g}$ for $5 \mathrm{~min}$ at $4^{\circ} \mathrm{C}$ and the pellet was dried briefly before being resuspended in $13.3 \mu \mathrm{L}$ of nuclease-free water (Ambion). Concentration was measured on a nano-drop UV-Vis spectrophotometer. Fifteen micrograms of decapped total RNA was incubated with rps 23 specific DNA splint and RNA anchor in DNA ligase buffer with T4 DNA ligase. The reaction was incubated at room temperature for $16 \mathrm{~h}$. The next morning, the sample was treated with DNaseI for $3 \mathrm{~h}$ at $37^{\circ} \mathrm{C}$ followed by phenol-chloroform extraction and ethanol precipitation for $2 \mathrm{~h}$ to overnight. RNA was pelleted and resuspended as previously, and the RNA concentration was determined. Five micrograms of this RNA was reverse transcribed using an rps23-specific primer and the Invitrogen Superscript III First-Strand Synthesis Kit. Two microliters of the reverse transcriptase reaction was used for PCR with primers either for total transcript or splinted-ligated product amplification. Products were resolved on a $\%$ TAE agarose gel and stained with SYBR Gold.

A similar procedure was followed for the in vitro transcribed and capped nano-luciferase mRNA. One hundred nanograms of purified transcript was incubated with $10 \mathrm{nM}$ of Dcp1-scEdc1Dcp2 for 30 $\min$ at $37^{\circ} \mathrm{C}$ before quenching the reaction with phenol-chloroform extraction. The rest of the splinted-ligation procedure was the same, except once the RNA was resuspended with $13.3 \mu \mathrm{L}$ nuclease-free water, then $1 \mu \mathrm{L}$ of the resuspension was used for the $16 \mathrm{~h}$ overnight splinted-ligation. After phenol-chloroform extraction, ethanol precipitation, and resuspension in water, $1 \mu \mathrm{L}$ of this purified product was used in the RT reaction and $1 \mu \mathrm{L}$ of this reaction was used as a template for PCR. The PCR product of the splint-ligated-specific forward primer and gene-specific reverse primer were purified following the standard QIAquick PCR Purification Kit (QIAGEN) protocol. $50 \mathrm{ng}$ total of PCR product was sent out locally to Quintara for Sanger sequencing with the gene-specific reverse primer.

\section{SUPPLEMENTAL MATERIAL}

Supplemental material is available for this article.

\section{ACKNOWLEDGMENTS}

We thank Joel Belasco for the gift of the plasmid encoding E. coli $\mathrm{RppH}$ and Bettie Osuna for the in vitro transcribed and capped RNA. The plasmid map was made using SnapGene software (from GSL Biotech; available at www.snapgene.com). This work was supported by US National Institutes of Health (R01 GM078360 to J.D.G. and National Research Service Award fellowship F32 GM105313 to J.S.M.) and the National Science Foundation (National Science Foundation predoctoral fellowship to D.R.P.).

Received June 29, 2017; accepted October 26, 2017.

\section{REFERENCES}

Barbosa C, Peixeiro I, Romão L. 2013. Gene expression regulation by upstream open reading frames and human disease. PLoS Genet 9: e1003529.

Blewett N, Coller J, Goldstrohm A. 2011. A quantitative assay for measuring mRNA decapping by splinted ligation reverse transcription polymerase chain reaction: qSL-RT-PCR. RNA 17: 535-543.

Borja MS, Piotukh K, Freund C, Gross JD. 2011. Dcp1 links coactivators of mRNA decapping to Dcp2 by proline recognition. RNA 17: 278-290.

Calvo SE, Pagliarini DJ, Mootha VK. 2009. Upstream open reading frames cause widespread reduction of protein expression and are polymorphic among humans. Proc Natl Acad Sci 106: 7507-7512.

Carninci P, Hayashizaki Y. 1999. High-efficiency full-length cDNA cloning. Methods Enzymol 303: 19-44.

Carninci P, Shibata Y, Hayatsu N, Sugahara Y, Shibata K, Itoh M, Kon Okazaki Y, Muramatsu M, Hayashizaki Y. 2000. Normalization and subtraction of cap-trapper-selected cDNAs to prepare full-length cDNA libraries for rapid discovery of new genes. Genome Res 10: $1617-1630$.

Curran JA, Weiss B. 2016. What is the impact of mRNA 5' TL heterogeneity on translational start site selection and the mammalian cellular phenotype? Front Genet 7: 156.

Deana A, Celesnik H, Belasco JG. 2008. The bacterial enzyme RppH triggers messenger RNA degradation by $5^{\prime}$ pyrophosphate removal. Nature 451: 355-358.

Dieudonné FX, O'Connor PBF, Gubler-Jaquier P, Yasrebi H, Conne B, Nikolaev S, Antonarakis S, Baranov PV, Curran J. 2015. The effect of heterogeneous transcription start sites (TSS) on the translatome: implications for the mammalian cellular phenotype. BMC Genomics 16: 986.

Grudzien-Nogalska E, Kiledjian M. 2017. New insights into decapping enzymes and selective mRNA decay. Wiley Interdiscip Rev RNA 8: e1379.

Jones BN, Quang-Dang DU, Oku Y, Gross JD. 2008. A kinetic assay to monitor RNA decapping under single- turnover conditions. Methods Enzymol 448: 23-40.

Lai T, Cho H, Liu Z, Bowler MW, Piao S, Parker R, Kim YK, Song H. 2012. Structural basis of the PNRC2-mediated link between mRNA surveillance and decapping. Structure 20: 2025-2037.

Lockard RE, Rieser L, Vournakis JN. 1981. Labeling of eukaryotic messenger RNA 5' terminus with phosphorus -32: use of tobacco acid pyrophosphatase for removal of cap structures. Gene Amplif Anal 2: 229-251.

Machida RJ, Lin YY. 2014. Four methods of preparing mRNA $5^{\prime}$ end libraries using the Illumina sequencing platform. PLoS One 9: e101812. 
Mugridge JS, Ziemniak M, Jemielity J, Gross JD. 2016. Structural basis of mRNA-cap recognition by Dcp1-Dcp2. Nat Struct Mol Biol 23: 987-994.

Rojas-Duran MF, Gilbert WV. 2012. Alternative transcription start site selection leads to large differences in translation activity in yeast. RNA 18: 2299-2305.

Schaefer BC. 1995. Revolutions in rapid amplification of cDNA ends: new strategies for polymerase chain reaction cloning of full-length cDNA ends. Anal Biochem 227: 255-273.

Schütz S, Noldeke ER, Sprangers R. 2017. A synergistic network of interactions promotes the formation of in vitro processing bodies and protects mRNA against decapping. Nucleic Acids Res 45: 6911-6922.

Valkov E, Muthukumar S, Chang CT, Jonas S, Weichenrieder O, Izaurralde E. 2016. Structure of the Dcp2-Dcp1 mRNA-decapping complex in the activated conformation. Nat Struct Mol Biol 23: 574-579.

Volloch V, Schweitzer B, Rits S. 1994. Ligation-mediated amplification of RNA from murine erythroid cells reveals a novel class of $\beta$ globin mRNA with an extended 5'-untranslated region. Nucleic Acids Res 22: 2507-2511.

Wang CY, Chen WL, Wang SW. 2013. Pdc1 functions in the assembly of P bodies in Schizosaccharomyces pombe. Mol Cell Biol 33: 12441253.

Wurm JP, Overbeck J, Sprangers R. 2016. The S. pombe mRNA decapping complex recruits cofactors and an Edcl-like activator through a single dynamic surface. RNA 22: 1360-1372.

Young SK, Wek RC. 2016. Upstream open reading frames differentially regulate gene-specific translation in the integrated stress response. $J$ Biol Chem 291: 16927-16935. 

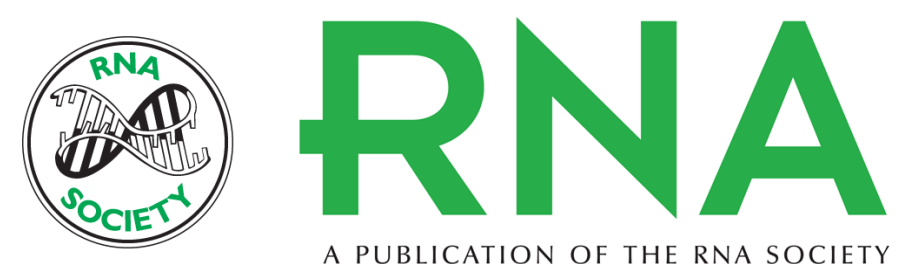

A PUBLICATION OF THE RNA SOCIETY

\section{Application of a Schizosaccharomyces pombe Edc1-fused Dcp1-Dcp2 decapping enzyme for transcription start site mapping}

David R. Paquette, Jeffrey S. Mugridge, David E. Weinberg, et al.

RNA 2018 24: 251-257 originally published online November 3, 2017

Access the most recent version at doi:10.1261/rna.062737.117

\section{Supplemental http://rnajournal.cshlp.org/content/suppl/2017/11/03/rna.062737.117.DC1 Material}

References This article cites 23 articles, 8 of which can be accessed free at: http://rnajournal.cshlp.org/content/24/2/251.full.html\#ref-list-1

Creative This article is distributed exclusively by the RNA Society for the first 12 months after the Commons License full-issue publication date (see http://rnajournal.cshlp.org/site/misc/terms.xhtml). After 12 months, it is available under a Creative Commons License (Attribution-NonCommercial 4.0 International), as described at http://creativecommons.org/licenses/by-nc/4.0/.
Email Alerting Receive free email alerts when new articles cite this article - sign up in the box at the Service top right corner of the article or click here.

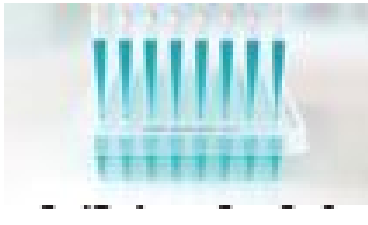

\section{Providing Precise Solutions for} your research.

To subscribe to $R N A$ go to:

http://rnajournal.cshlp.org/subscriptions 